\title{
A new method for the capture of surface proteins in Plasmodium falciparum parasitized erythrocyte
}

\author{
Emanuela Ferru ${ }^{1,2}$, Antonella Pantaleo ${ }^{3}$, Francesco Turrini ${ }^{1}$ \\ ${ }^{1}$ Department of Genetics, Biology and Biochemistry, University of Turin, 10126 Turin, Italy \\ ${ }^{2}$ CELLSURF, Sassari, 07100, Italy \\ ${ }^{3}$ Department of Biomedical Sciences, University of Sassari, 07100, Italy
}

\begin{abstract}
Introduction: We propose a new method for the selective labeling, isolation and electrophoretic analysis of the Plasmodium falciparum protein exposed on the erythrocyte cell surface. Historically, membrane surface proteins have been isolated using a surface biotinylation followed by capture of biotin-conjugated protein via an avidin/streptavidin-coated solid support. The major drawback of the standard methods has been the labeling of internal proteins due to fast internalization of biotin.

Methodology: To solve this problem, we used a biotin label that does not permeate through the membrane. As a further precaution to avoid the purification of non surface exposed proteins, we directly challenged whole labeled cells with avidin coated beads and then solubilized them using non ionic detergents.

Results: A marked enrichment of most of the RBC membrane proteins known to face the external surface of the membrane validated the specificity of the method; furthermore, only small amounts of haemoglobin and cytoskeletal proteins were detected. A wide range of $P$. falciparum proteins were additionally described to be exposed on the erythrocyte surface. Some of them have been previously observed and used as vaccine candidates while a number of newly described antigens have been presently identified. Those antigens require further characterization and validation with additional methods.

Conclusion: Surface proteins preparations were very reproducible and identification of proteins by mass spectrometry has been demonstrated to be feasible and effective.
\end{abstract}

Key words: Plasmodium falciparum; erythrocyte; malaria; surface protein

J Infect Dev Ctries 2012; 6(6):536-541.

(Received 10 November 2011 - Accepted 30 December 2011)

Copyright $(\odot) 2012$ Ferru et al. This is an open-access article distributed under the Creative Commons Attribution License, which permits unrestricted use, distribution, and reproduction in any medium, provided the original work is properly cited

\section{Introduction}

The erythrocyte membrane undergoes profound changes during the intracellular development of malaria parasites. Plasmodium falciparum induces a vast array of modifications from the early phases of its growth with the insertion of ring-infected erythrocyte surface antigen (RESA) and additional proteins occurring immediately after invasion [1-4], and with an increasing number of proteins inserted at the trophozoite and schizont stages [5,6]. Additionally, several modifications also involve red cell membrane proteins and cause overall reorganization of the parasitized erythrocyte membrane [7-10]. The reorganization of the host cell membrane has a functional role during the later stages of parasite growth, ending in erythrocyte membrane disruption and parasite egress [11-13]. The development of a powerful immune response to the parasitized erythrocyte membrane components is the counterpart of such modifications. Deeper knowledge of surface modifications of malaria parasitized erythrocytes is required for the design of new vaccines [14-16].
Unfortunately, the impressive genetic variability of the major malaria antigens such as PfEMP1 partially defuse the effectiveness of the immune response, which apparently takes years to adapt to the antigenic complexity of the parasite and to acquire proficiency [17-19]. Lack of adequate immune response is considered to be one of the major causes of severe complications in young children. For this reason the development of vaccines aimed at speeding up an effective immune response in children remains one of the major goals of malaria research. Analysis and monitoring of the immune response to malaria would require expensive and complicated methodological approaches such as protein microarrays containing hundreds of recombinant antigen domains. The assessment of the functional meaning of such results would also require further information about the extracellular accessibility of the epitopes.

In this report we present a relatively simple and very reproducible method to isolate surface exposed proteins in parasitized erythrocytes based on biotin labeling and capture through surface- 
surface interactions. The results have been validated through immunological and proteomic methodologies demonstrating that this technique may represent a consistent approach for the analysis and monitoring of effective surface directed immunological responses to malaria.

\section{Methodology}

Cultivation of $\mathrm{P}$. falciparum- $R B C$ membranes

Freshly drawn blood $(\mathrm{Rh}+)$ from healthy adults of both sexes was used, after being anticoagulated with heparin and kept in citrate-phosphate-dextrose with adenine (CPDA-1). Red blood cells (RBC) were separated from plasma and leukocytes by three washings in wash medium (RPMI 1640 medium containing $2 \mathrm{mM}$ glutamine, $24 \mathrm{mM}$ NaHCO3, $25 \mathrm{mM}$ HEPES, $20 \mathrm{mM}$ glucose, and 32 $\mathrm{mg}$ of gentamicin per liter [pH 6.80]). P falciparum strain Palo Alto (mycoplasma free) was cultivated at a $0.5 \%$ hematocrit and synchronized as described previously [20]. P. falciparum RBCs with different maturation stages at 14 hours to 18 hours (rings) or 34 hours to 38 hours (trophozoites), were studied. The parasitemia proportions were usually $20 \%$. To assess total parasitemia and the relative contributions of rings and trophozoites, slides were prepared from cultures at the indicated times and stained with Diff-Quik kit stain (Fisher Scientific, Pittsburgh, USA) and 400 to 1,000 cells were examined microscopically.

\section{Isolation of normal and parasitized erythrocyte surface proteins}

Briefly, $1 \mathrm{ml}$ of control and parasitized (Trophozoite stage) packed erythrocytes were incubated for 10 minutes with $0.5 \mathrm{mg} / \mathrm{ml}$ of SulfoNHS-Biotin (Pierce) at $4^{\circ} \mathrm{C}$ under gentle mixing. The reaction was stopped by three washes with phosphate buffer saline $(137 \mathrm{mM} \mathrm{NaCl}, 2.7 \mathrm{mM}$ $\mathrm{KCl}, 8.1 \mathrm{mM}$ K2HPO4, $1.5 \mathrm{mM} \mathrm{KH} 2 \mathrm{PO} 4, \mathrm{pH} 7.4$ ) in the presence of glucose $5 \mathrm{mM}$ at $\mathrm{pH} 7.4$ (PBSglucose) and pelleted at $1000 \mathrm{x}$ g for 4 minutes in a refrigerated centrifuge at $4^{\circ} \mathrm{C}$. Biotinylated surface proteins from control and parasitized packed erythrocytes were incubated with avidin-agarose beads $\left(500 \mu \mathrm{l} / \mathrm{ml}\right.$ of cells) for 30 minutes at $4^{\circ} \mathrm{C}$. Samples were pelleted at $1500 \mathrm{x}$ g in a refrigerated centrifuge at $4{ }^{\circ} \mathrm{C}$. After removal of the supernatant, 15 volumes of cold hemolysis buffer ( $1 \%$ Triton X$100,5 \mathrm{mM}$ DDT, 5mM EDTA) in the presence of a protease inhibitor cocktail (Sigma-Aldrich, St. Louis, MO, USA) were added to the samples. Unbound components were removed by three washes at $15.000 \mathrm{x} \mathrm{g}$ using a cold hemolysis buffer. Proteins captured on the surface of the beads were eluted with Laemmli buffer at a volume ratio of
$1: 1$, heated for 5 minutes at $100^{\circ} \mathrm{C}$, and then separated electrophoretically in $6 \%-15 \%$ gradient polyacrylamide gel, $20 \times 20 \mathrm{~cm}$. Protein content was quantified using the DC Protein Assay (Biorad, Hercules, CA, USA). Next $50 \mu \mathrm{g}$ of control and $150 \mu \mathrm{g}$ of parasitized erythrocyte proteins were loaded for each lane. Electrophoresis was performed for 15 minutes at $50 \mathrm{~V}$ and then continued at $150 \mathrm{~V}$. Proteins from SDS-PAGE were stained with colloidal Coomassie Blue. All SDS/PAGE experiments were performed at least in triplicate.

\section{Identification by MALDI-TOF MS}

Isolated surface proteins were identified by mass spectrometry. Bands were excised from SDS/PAGE and proteins were digested with trypsin. Bands were destained by way of several washes in $5 \mathrm{mM} \mathrm{NH} 4 \mathrm{HCO} / \mathrm{ACN}$ (acetonitrile) $(50 / 50 \mathrm{v} / \mathrm{v})$ and successively dried with pure ACN. The gel slices were rehydrated for 45 minutes at $4^{\circ} \mathrm{C}$ in $20 \mu 1$ of $5 \mathrm{mM} \mathrm{NH} 4 \mathrm{HCO} 3$ digestion buffer containing $10 \mathrm{ng} / \mu \mathrm{L}$ of trypsin. Excess protease solution was removed and the volume adjusted with $5 \mathrm{mM}$ NH4HCO3 to cover the gel slices. Digestion was allowed to proceed overnight at $37^{\circ} \mathrm{C}$.

Samples were loaded onto a MALDI target using $1 \mu \mathrm{L}$ of the tryptic digests mixed 1:1 with a solution of CHCA (alpha-Cyano-4hydroxycinnamic acid) $(10 \mathrm{mg} / \mathrm{ml}$ in ACN/TFA $0.1 \%, 40 / 60)$. MS analysis of peptides was performed as previously describe [7].

\section{Immunoblot analysis}

Following the mapping of the $\mathrm{P}$ falciparum surface proteome, malaria antigens were stained by SDS/PAGE western blotting using specific antibodies and immune sera kindly provided by the Pasteur Institute (Paris).

Membranes were probed with anti-G8 and antitR96 (both developed in rabbit); with anti-band 3, anti-HrpI, anti-Heat shock protein 70 and 90, antiRhopH, anti-Hrp II (developed in mouse); with a healthy human serum; and with a pool of malaria hyper-immune sera. All the antibodies were diluted 1:50 and incubated for 1 hour. After three washes with PBS/ tween $01 \%$, the membranes were incubated with specific secondary antibody conjugated with alkaline phosphatase.

\section{Results}

Isolation of surface proteins and their proteomic characterization

We isolated surface membrane proteins from trophozoite parasitized erythrocytes. To minimize the labeling of internal proteins we used a non 
permeable cross-linker (Sulfo-NHS biotin) for a short period at $4^{\circ} \mathrm{C}$. Cells were then incubated with avidin bound agarose beads to allow the binding of biotinylated / surface exposed proteins to the beads. After extensive washing of non adherent cells, we added a nonionic detergent to wash out all cellular components that were not directly bound to the beads surface. Proteins bound to the avidin coated beads were then eluted using SDS and separated by SDS/PAGE. Figure 1 shows the results obtained with control and parasitized erythrocytes after Coomassie Blue staining (lanes 2, 4). Table 1 shows the list of all proteins identified by mass spectrometry of the bands visualized in the gels. Relatively few proteins were separated from control erythrocyte surfaces while a much higher number of proteins were isolated from parasitized erythrocytes. A total of 18 out of 29 protein bands belonged to the parasites, while the rest belonged to the host cell. Performing replicate experiments we observed a good reproducibility of the results.

It is important to note that some of the identified proteins, such as spectrins, actin and protein 4.1 , are part of the cytoskeletal complex. Their presence in extracted surface membrane proteins could be due to their tight interaction with transmembrane proteins such as band 3 [21,22] and PfEMP1[23].

\section{Immunological characterization of the surface proteins}

To test the antigenicity of the isolated surface proteins using the same surface isolated proteins, we then performed a western blot with a pool of hyper-immune sera (Figure 1, lanes 1, 3). Approximately 12 protein bands reacted with the sera indicating their antigenicity. Notably, no reactivity was observed with non-parasitized human erythrocytes. Some proteins such as RhopH 1 and Rhoptry 2 (bands 11, 12) and elongation factor 2 (band 15) appear to correspond to known malaria antigens. All other antigens require further validation using additional methods for their unequivocal identification.

\section{Validation of the methodology to isolate surface exposed proteins}

To validate the method we tested our isolated surface proteins using high affinity antibodies directed to proteins known to be not surface expressed, such as HSP 70 and 90, and to proteins known to be surface exposed, such as tR96, G8, and band 3 (Table 2). Figure 2 shows that western blots were positive only with antibodies directed to known surface exposed proteins while no reactivity was observed with antibodies for internal antigens.
Those data therefore demonstrate that the hereby developed methodology is able to effectively enrich surface exposed proteins.

\section{Discussion}

The characterization of the surface antigenic modifications induced by the intracellular growth of $P$. falciparum still represents a major challenge for the development of malaria vaccines and for the understanding of the wide variability of clinical responses to malaria. So far, many genetic and proteomic approaches have been used [24-27] that have provided valuable information about $P$. falciparum antigens and their use for vaccine development; however, direct evidence about the actual surface expression of the antigens would be of great value in selecting new targets.

The present report demonstrates that it is possible to isolate surface proteins from $P$. falciparum parasitized erythrocyte cultures using a simple method that is both labor and cost effective. The protein patterns obtained with replicate experiments reveal significant reproducibility and a consistent enrichment of surface proteins. Western blot analysis of the cell surface isolated proteins using hyper-immune sera demonstrated that several proteins are highly immunogenic, and therefore represent potential candidates for vaccine development. While some of these proteins such as Rhoptry are known to be malaria antigens and have been easily identified, most of our results require additional validation using different methodologies.

Proteomic analysis of surface isolated proteins revealed the presence of membrane proteins with little contamination by proteins known to be not surface expressed. The method could be easily parallelized to increase its throughput and further decrease cost and labor efficiency. The present methodology could be therefore applied to fresh isolates for the study of the variability of parasite strains and to analyze the individual immune responses. This methodology also could be readily used to study the age dependent development of an immune response directed to surface determinants, the interference of human protective mutations, and the effect of antimalarial therapy. 
Table 1. Surface membrane proteins identified by MALDI-Tof analysis.

\begin{tabular}{|c|c|c|c|c|c|}
\hline $\mathbf{N}$ & Protein & Species & MW & Score & Coverage \\
\hline 1 & Spectin alpha & Hum & 279,7 & 140 & 22 \\
\hline 2 & Spectrin beta & Hum & 246 & 183 & 36 \\
\hline 3 & Band 3 & Hum & 102 & 70 & 13 \\
\hline 4 & Band 3 & Hum & 102 & 91 & 16 \\
\hline 5 & Band 4.2 & Hum & 77 & 93 & 17 \\
\hline 6 & Actin & Hum & 41,7 & 82 & 9 \\
\hline 7 & Tropomodulin & Hum & 34 & 53 & 13 \\
\hline 8 & Spectin alpha & Hum & 279,7 & 44 & 27 \\
\hline 9 & Spectrin beta & Hum & 246 & 106 & 27 \\
\hline 10 & Spectrin beta & Hum & 246 & 91 & 15 \\
\hline 11 & RhopH 1 & $\mathrm{P} f$ & 168,7 & 70 & 11 \\
\hline 12 & Rhoptry 2 & $\mathrm{Pf}$ & 168,7 & 88 & 21 \\
\hline 13 & Glicophorin binding protein & $\mathrm{P} f$ & 95,8 & 66 & 10 \\
\hline 14 & Band 3 & Hum & 102 & 117 & 15 \\
\hline \multirow[t]{2}{*}{15} & Band 3 & Hum & 102 & 54 & 7 \\
\hline & Elongation factor 2 & $\mathrm{P} f$ & 93,4 & 71 & 11 \\
\hline \multirow[t]{2}{*}{16} & Band 3 & Hum & 102 & 81 & 14 \\
\hline & HSP 86 & $\mathrm{P} f$ & 86 & 71 & 10 \\
\hline 17 & Band 3 & Hum & 102 & 47 & 12 \\
\hline \multirow[t]{2}{*}{18} & Band 4.1 & Hum & 97 & 87 & 18 \\
\hline & Band 3 & Hum & 102 & 49 & 13 \\
\hline 19 & Band 4.2 & Hum & 77 & 99 & 16 \\
\hline 20 & Band 4.2 & Hum & 77 & 109 & 16 \\
\hline 21 & Band 3 & Hum & 102 & 81 & 14 \\
\hline \multirow[t]{2}{*}{22} & Band 3 & Hum & 42,5 & 95 & 8 \\
\hline & Catalase & Hum & 59,6 & 53 & 6 \\
\hline 23 & EMP1 & $\mathrm{P} f$ & 14,3 & 55 & 5 \\
\hline \multirow[t]{2}{*}{24} & Beta tubulin & $\mathrm{Pf}$ & 49,7 & 65 & 7 \\
\hline & Pyruvate kinase & $\mathrm{P} f$ & 55,6 & 117 & 10 \\
\hline 25 & Elongation factor 1 & $\mathrm{P} f$ & 49 & 94 & 10 \\
\hline 26 & Actin & Hum & 41,7 & 110 & 11 \\
\hline 27 & Actin & Hum & 41,7 & 129 & 14 \\
\hline 28 & $\begin{array}{l}\text { Phosphoribosyl- } \\
\text { pyrophosphate synthetase }\end{array}$ & $\mathrm{P} f$ & 49,3 & 79 & 8 \\
\hline 29 & $\begin{array}{l}\text { Endoplasmatic retic-rest } \\
\text { calcium binding protein }\end{array}$ & $\mathrm{P} f$ & 39,3 & 42 & 6 \\
\hline 30 & Elongation factor 1B & $\mathrm{P} f$ & 32 & 54 & 6 \\
\hline 31 & L. lactate dehydrogenase & $\mathrm{Pf}$ & 34 & 92 & 10 \\
\hline 32 & L. lactate dehydrogenase & $\mathrm{P} f$ & 34 & 63 & 7 \\
\hline 33 & Hemoglobin & Hum & 15,9 & 68 & 6 \\
\hline 34 & Hemoglobin & Hum & 15,9 & 101 & 8 \\
\hline 35 & Hemoglobin & Hum & 15,9 & 52 & 7 \\
\hline 36 & Hemoglobin & Hum & 15,9 & 70 & 6 \\
\hline 37 & 2-Cys peroxiredoxin & $\mathrm{P} f$ & 21,8 & 60 & 5 \\
\hline \multirow[t]{2}{*}{38} & 2-Cys peroxiredoxin & $\mathrm{P} f$ & 21,8 & 65 & 6 \\
\hline & EMP & $\mathrm{P} f$ & 14,3 & 57 & 5 \\
\hline \multirow[t]{2}{*}{39} & Hemoglobin & Hum & 15,9 & 69 & 11 \\
\hline & $96 \mathrm{tR}$ antigen & $\mathrm{P} f$ & 17,6 & 107 & 9 \\
\hline 40 & Hemoglobin & Hum & 15,9 & 89 & 9 \\
\hline
\end{tabular}

Numbers correspond with the band numbered in figure 1. 
Table 2. Antibodies used to validate surface membrane protein isolation method.

\begin{tabular}{|l|l|l|l|}
\hline Lane & Antibody & Site & Reactivity \\
\hline 1 & Anti-G8 & Esternal & Positive \\
\hline 2 & Anti-Band 3 & Trans-membrane & Positive \\
\hline 3 & Hrp I & Internal & Negative \\
\hline 4 & HSP 70 & Internal & Negative \\
\hline 5 & HSP 90 & Internal & Negative \\
\hline 6 & Anti-RhopH & Esternal & Positive \\
\hline 7 & Hrp II & Internal & Negative \\
\hline 8 & tR 96 & Esternal & Positive \\
\hline 9 & Healthy human serum & Esternal & Negative \\
\hline 10 & Pool of malaria hyper-immune sera & Esternal & Positive \\
\hline
\end{tabular}

Numbers of listed antibodies correspond with lane numbers in the figure 2 .

Figure 1. Surface membrane proteins identification

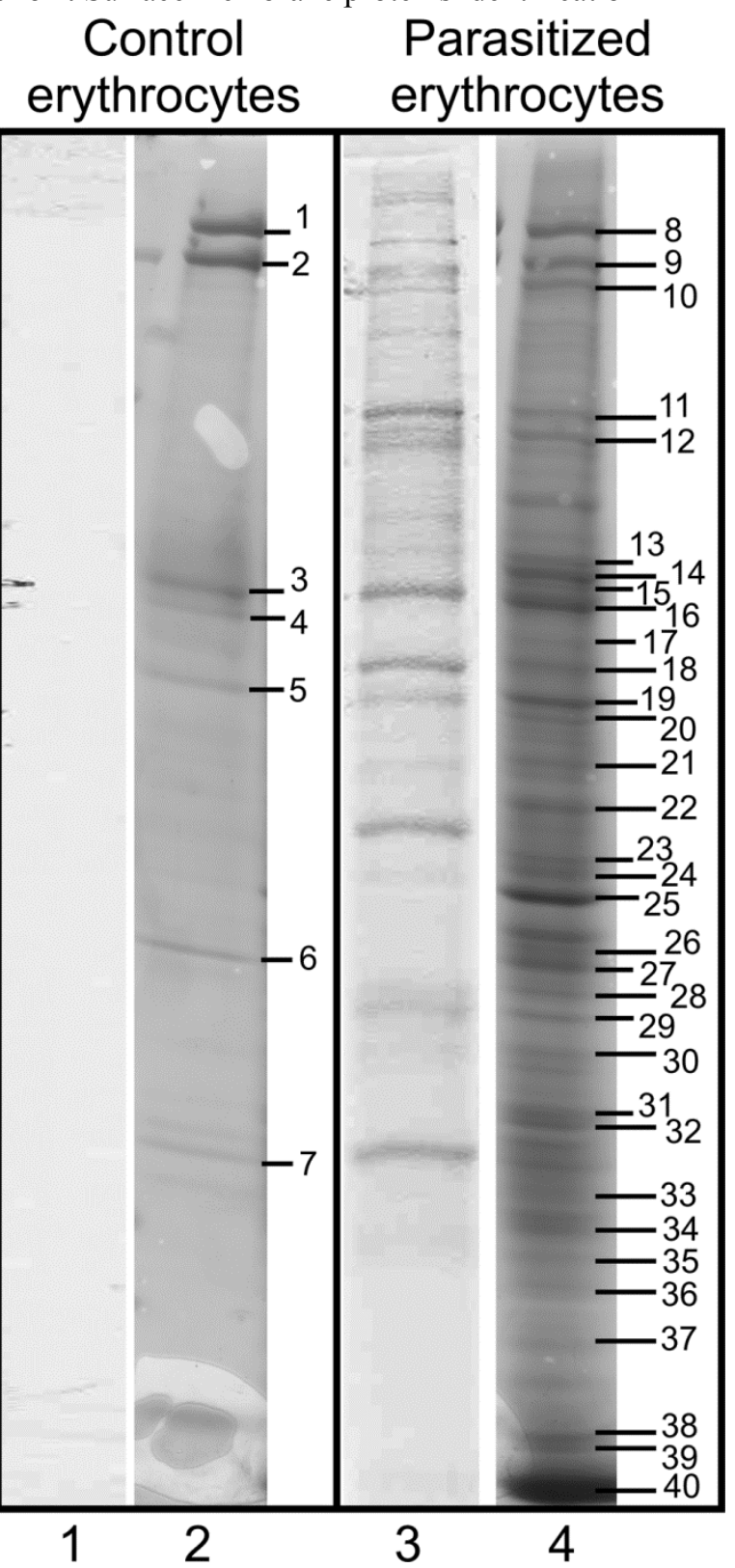

Isolated surface proteins from control (lanes 1, 2) and parasitized erythrocytes (lanes 3,4) were separated by $10 \%$ SDS-PAGE and blotted on nitrocellulose membrane stained with a pool of malaria hyper-immune sera (lanes 1, 3) or stained by Blue colloidal Coomassie (lanes 2, 4). Proteins numbered in lanes 2 and 4 were identified by mass spectrometry and listed in table 1 .
Figure 2. Validation of the surface membrane protein isolation methodology

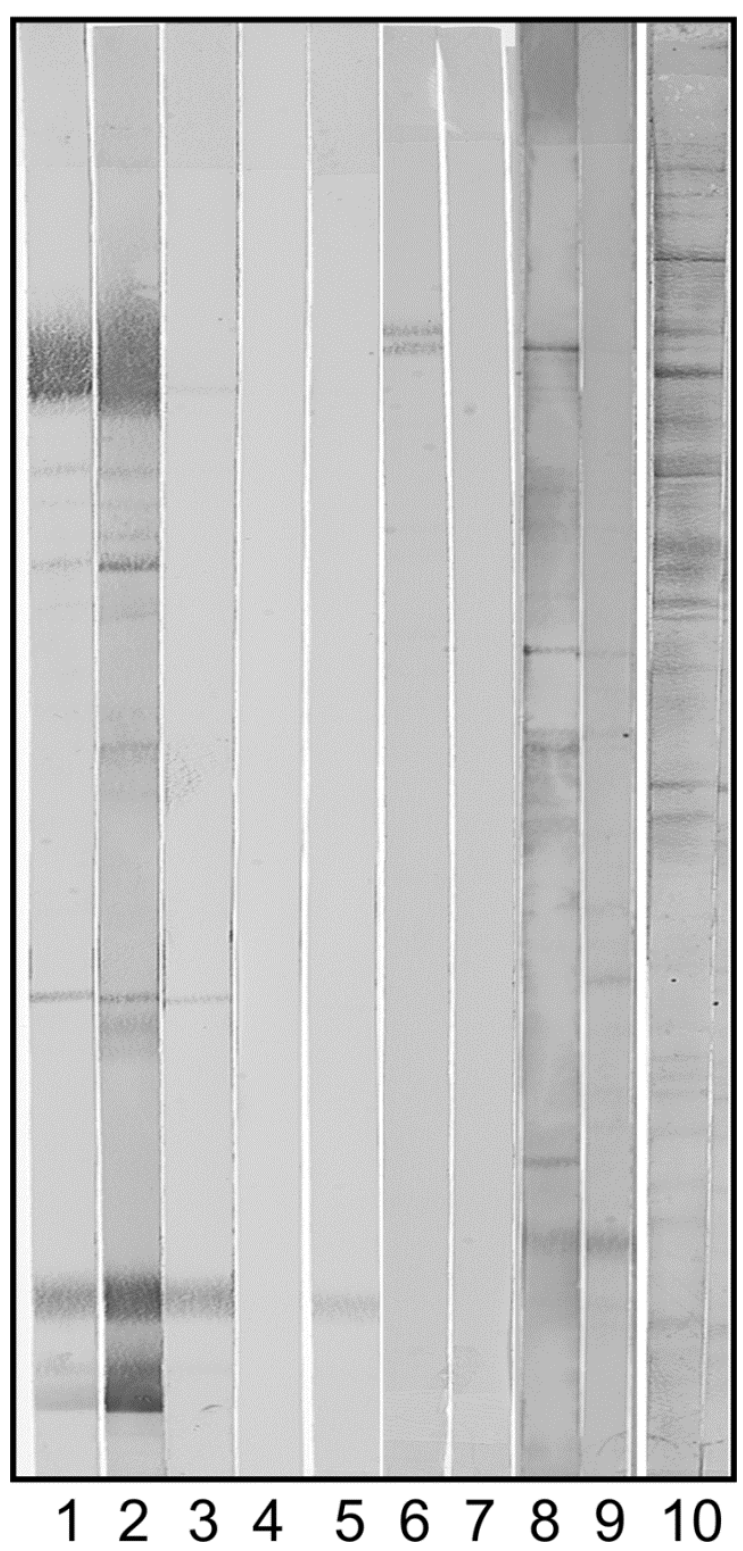

Extracted surface protein from parasitized erythrocytes were separated by $10 \%$ SDS-PAGE and blotted on nitrocellulose membrane stained with specific antibodies listed in table 2 . 


\section{Acknowledgement}

This work was supported by Regione Autonoma della Sardegna "legge regionale 7 Agosto 2007" : Promozione della ricerca scientifica e dell'innovazione in Sardegna

\section{References}

1. Dluzewski AR, Fryer PR, Griffiths S, Wilson RJ, Gratzer WB (1989) Red cell membrane protein distribution during malarial invasion. J Cell Sci 92: 691-699.

2. Haldar K and Mohandas N (2007) Erythrocyte remodeling by malaria parasites. Curr Opin Hematol 14: 203-209.

3. Pei X, Guo X, Coppel R, Bhattacharjee S, Haldar K, Gratzer W, Mohandas N, An X (2007) The ring-infected erythrocyte surface antigen (RESA) of Plasmodium falciparum stabilizes spectrin tetramers and suppresses further invasion. Blood 110: 1036-1042.

4. Da Silva E, Foley M, Dluzewski AR, Murray LJ, Anders RF, Tilley L (1994) The Plasmodium falciparum protein RESA interacts with the erythrocyte cytoskeleton and modifies erythrocyte thermal stability. Mol Biochem Parasitol 66: 59-69.

5. Maier AG, Cooke BM, Cowman AF, Tilley L (2009) Malaria parasite proteins that remodel the host erythrocyte. Nat Rev Microbiol 7: 341-354.

6. Glenister FK, Coppel RL, Cowman AF, Mohandas N, Cooke BM (2002) Contribution of parasite proteins to altered mechanical properties of malaria-infected red blood cells. Blood 99: 1060-1063.

7. Pantaleo A, Ferru E, Carta F, Mannu F, Giribaldi G, Vono R, Leppedda AJ, Pippia P, Turrini F (2010) Analysis of changes in tyrosine and serine phosphorylation of red cell membrane proteins induced by $P$. falciparum growth. Proteomics 10: 3469-3479.

8. Parker PD, Tilley L, Klonis N (2004) Plasmodium falciparum induces reorganization of host membrane proteins during intraerythrocytic growth. Blood 103: 2404-2406.

9. Tilley L, Dixon MW, Kirk K (2011) The Plasmodium falciparum-infected red blood cell. Int J Biochem Cell Biol 43: 839-842.

10. Cooke BM, Mohandas N, Coppel RL (2004) Malaria and the red blood cell membrane. Semin Hematol 41: 173188.

11. Heussler V, Rennenberg A, Stanway R (2010) Host cell death induced by the egress of intracellular Plasmodium parasites. Apoptosis 15: 376-385.

12. Soni S, Dhawan S, Rosen KM, Chafel M, Chishti AH, Hanspal M (2005) Characterization of events preceding the release of malaria parasite from the host red blood cell. Blood Cells Mol Dis 35: 201-211.

13. Abkarian M, Massiera G, Berry L, Roques M, BraunBreton C (2011) A novel mechanism for egress of malarial parasites from red blood cells. Blood 117: 41184124.

14. Goodman AL, Draper SJ (2010) Blood-stage malaria vaccines - recent progress and future challenges. Ann Trop Med Parasitol 104: 189-211.

15. Hafalla JC, Silvie O, Matuschewski K (2011) Cell biology and immunology of malaria. Immunol Rev 240: 297-316.

16. Moorthy VS KM (2010) Reducing empiricism in malaria vaccine design. Lancet Infectious Diseases 10: 204-211.
17. Barry AE, Trieu A, Fowkes FJ, Pablo J, KalantariDehaghi M, Jasinskas A, Tan X, Kayala MA, Tavul L, Siba PM, Day KP, Baldi P, Felgner PL, Doolan DL (2011) The stability and complexity of antibody responses to the major surface antigen of Plasmodium falciparum are associated with age in a malaria endemic area. Mol Cell Proteomics 10: M111 008326.

18. Arnot DE and Jensen AT (2011) Antigenic variation and the genetics and epigenetics of the PfEMP1 erythrocyte surface antigens in Plasmodium falciparum malaria. Adv Appl Microbiol 74: 77-96.

19. Borrmann S and Matuschewski K (2011) Protective immunity against malaria by 'natural immunization': a question of dose, parasite diversity, or both? Curr Opin Immunol 23: 500-508.

20. Lambros C, Vanderberg JP (1979) Synchronization of Plasmodium falciparum erythrocytic stages in culture. J Parasitol 65: 418-420.

21. Bruce LJ, Beckmann R, Ribeiro ML, Peters LL, Chasis JA, Delaunay J, Mohandas N, Anstee DJ, Tanner MJ (2003) A band 3-based macrocomplex of integral and peripheral proteins in the RBC membrane. Blood 101: 4180-4188.

22. Bennett V (1983) Proteins involved in membrane-cytoskeleton association in human erythrocytes: spectrin, ankyrin, and band 3. Methods Enzymol 96: 313-324.

23. Oh SS, Voigt S, Fisher D, Yi SJ, LeRoy PJ, Derick LH, Liu S, Chishti AH (2000) Plasmodium falciparum erythrocyte membrane protein 1 is anchored to the actinspectrin junction and knob-associated histidine-rich protein in the erythrocyte skeleton. Mol Biochem Parasitol 108: 237-247.

24. Cardoso FC, Roddick JS, Groves P, Doolan DL (2011) Evaluation of approaches to identify the targets of cellular immunity on a proteome-wide scale. PLoS One 6: e27666.

25. Doolan DL (2011) Plasmodium immunomics. Int J Parasitol 41: 3-20.

26. Cai Q, Peng G, Bu L, Lin Y, Zhang L, Lustigmen S, Wang H (2007) Immunogenicity and in vitro protective efficacy of a polyepitope Plasmodium falciparum candidate vaccine constructed by epitope shuffling. Vaccine 25: 5155-5165.

27. Sanders PR, Gilson PR, Cantin GT, Greenbaum DC, Nebl T, Carucci DJ, McConville MJ, Schofield L, Hodder AN, Yates JR 3rd, Crabb BS (2005) Distinct protein classes including novel merozoite surface antigens in Raft-like membranes of Plasmodium falciparum. J Biol Chem 280: 40169-40176.

\section{Correpsonding author \\ Emanuela Ferru}

Department of Genetics, Biology and Biochemistry

University of Turin

10126 Turin, Italy

Telephone: +390792677000

Email: emanuela.ferru@tiscali.it

Conflict of interests: No conflict of interests is declared. 